\title{
How do children build knowledge in early childhood education? Susan Isaacs, Young Children Are Researchers and what happens next
}

\author{
Jane Murray
}

To cite this article: Jane Murray (2021): How do children build knowledge in early childhood education? Susan Isaacs, Young Children Are Researchers and what happens next, Early Child Development and Care, DOI: 10.1080/03004430.2020.1854242

To link to this article: https://doi.org/10.1080/03004430.2020.1854242

\section{( C) 2021 The Author(s). Published by Informa UK Limited, trading as Taylor \& Francis} Group

\section{曲 Published online: 17 Jan 2021.}

Submit your article to this journal $₫$

Џلll Article views: 301

Q View related articles $匚$

View Crossmark data $\nearrow$ 


\section{How do children build knowledge in early childhood education? Susan Isaacs, Young Children Are Researchers and what happens next}

Jane Murray

Faculty of Health, Education and Society, Centre for Education and Research, University of Northampton, Northampton, UK

\begin{abstract}
This article considers the relevance of Susan Isaacs' practice and research for twenty-first century early childhood education, reflected in two studies conducted discretely nearly a century apart that theorize young children's constructions of knowledge: Isaacs' Malting House School study and the 'Young Children Are Researchers' study. The article reviews Isaacs' work with particular focus on 'discovery, reasoning and thought', her values and three key disciplines that informed her practice and research: pedagogy, philosophy and psychology. Selected findings from Isaacs' Malting House School Study and the 'Young Children Are Researchers' study are critiqued to build the argument that not only has Isaacs' work left a powerful legacy to the field of early childhood education, but that it also has potential to benefit the field now and into the future. However, this proposition is contingent on early childhood educators who are highly knowledgeable and skilled: factors that have policy implications.
\end{abstract}

\section{ARTICLE HISTORY}

Received 14 October 2020

Accepted 17 November 2020

\section{KEYWORDS}

Susan Isaacs; children are researchers; values; disciplines; child-led learning; child-led pedagogy

\section{Introduction}

This article considers the relevance of Susan Isaacs' practice and research for twenty-first century early childhood education (ECE), reflected in two studies conducted discretely almost a century apart that theorize young children's constructions of knowledge: Susan Sutherland Isaacs' Malting House School (MHS) study $(1930,1933)$ and the Young Children Are Researchers (YCAR) study (Murray, 2017). Isaacs' values, practice, research and the enduring significance of the consilience of the disciplines pedagogy, philosophy and psychology (PPP) that she pioneered for the ECE field are explored to support the argument that her work not only left a powerful legacy but has potential to benefit the ECE field now and into the future. However, this proposition is contingent on early childhood educators who are highly knowledgeable and highly skilled: factors that have policy implications.

The article opens with a short review of PPP including brief allusion to Isaacs' work. Values in ECE and related disciplines are then addressed ahead of more fulsome discussion concerning Isaacs, her engagement with PPP and her continuing influence on the ECE field. Consideration is made of a range of selected studies that draw on PPP to recognize young children's adoption of epistemic cognition for constructing knowledge (Greene, Azevedo, \& Torney-Purta, 2008). The research designs of the MHS and YCAR studies are then outlined in more detail before selected findings from these 
studies are examined with focus on how consilience of PPP was applied to elicit findings in each (Isaacs, 1930; Murray, 2017). The article concludes by discussing implications of findings from the two studies for supporting young children's learning in the twenty-first century.

\section{Consilience of pedagogy, philosophy and psychology}

Consilience is the production of knowledge by connecting 'facts and fact-based theory across disciplines to create a common groundwork of explanation' (Wilson, 1998, p. 6). The consilience of the three disciplines PPP informed Isaac's work as an early childhood educator and teacher educator during the first half of the twentieth century (Gardner, 1969). Her influence on education in England has been significant (Hood, 2019; Willan, 2009, 2011); indeed, I have experienced that influence in my own education in England in the 1960s and 1970s and in my career since 1980 as a pre-service teacher, ECE and primary school teacher, teacher educator and researcher have also been informed by PPP. This section defines the three disciplines separately, and briefly explores Isaacs' engagement with them.

\section{Pedagogy}

Pedagogy is defined as 'instructional techniques and strategies that enable learning to take place' (Sylva, Melhuish, Sammons, Siraj-Blatchford, \& Taggart, 2010, p. 149). However, pedagogy is multifaceted (Murray, 2015). For example, adult-led transmission teaching requires the knowledgeable teacher to convey information to passive learners (Nola \& Irzik, 2006). Alternatively, for interactionist pedagogy, learning is co-constructed by children and teachers (Edwards, Gandini, \& Forman, 1993). In child-led pedagogy, children construct their own learning freely and independently 'through play and discovery' according to their own interests as 'active learners' (Rugg \& Shumaker, 1928; Ryan, 2005, p. 99). Isaacs was a trained infant teacher for whom child-led pedagogy was the preferred approach (Isaacs, 1930, 1954); she acknowledged Dewey $(1897,1916)$ and Montessori (1912) as influences in this regard. Isaacs' pedagogy also chimed strongly with Froebel's (1826) yet is tacit concerning his work in her publications relating to MHS (Isaacs, 1930,1933), possibly because he was not in vogue when she was at the school (Chung \& Walsh, 2000).

\section{Philosophy}

Philosophy is an ancient discipline comprising various branches (Gibney, 2012). It is a logical 'way of thinking about certain sorts of question' (Warburton, 2013, p. 1), including 'What is there?' 'What should we do?' 'How do we know?' and 'How can we find out?' (Craig, 2002, p. 1). The last two questions are epistemological: concerned with justification and knowledge (Audi, 1998). They provide fundamental underpinning for the diverse ways research is conducted to produce knowledge (Lather, 2006). These two epistemological questions were of central importance to Isaacs' work, in terms of what educators should ask themselves and what young children ask in many ways in their everyday activities (Isaacs, 1930). As a philosophy graduate, Isaacs (1930, p. 22) regarded the processes young children use to think for 'finding out' to be a primary concern of 'the philosophy of education'.

\section{Psychology}

Originally a branch of philosophy (Wertheimer \& Puente, 2020), psychology became a discrete discipline by the late nineteenth century through the work of pioneers including Wundt (1896) and James (1890). Psychology is recognized as 'the scientific study of the mind and how it dictates and influences our behaviour' (British Psychological Society [BPS], 2020), a definition that has changed little since James' (1890, p. 1) - 'the Science of Mental Life, both of its phenomena and 
of their conditions' - which prevailed when Isaacs studied for her Master's degree in psychology at Cambridge in 1913. Like philosophy, psychology is constituted of numerous strands, including psychoanalysis: a 'theory of psychopathology and a treatment for mental disorders', and a contested area (American Psychological Association (APA), 2020; Paris, 2017, p. 308). Psychoanalysis was a great interest of Isaacs' (Graham, 2008). However, while Isaacs (1933, p. 19) acknowledged that psychoanalytic theory informed her principle that play has 'great educational value', she was adamant that MHS educational provision was not based on psychoanalytic theory. At MHS, Isaacs adopted procedures common to the wider field of psychology: she conducted research using 'observation, experimentation and analysis', and she based her theorization on these data (APA, 2020).

\section{Values in early childhood education}

Values permeate disciplines, are transmitted through socialization, and are a prominent feature of ECE (Giannoni, 2010; Murray, 2018), not least because ECE strongly influences young children's lives (Powell, 2010). Early childhood teacher education often transmits the values and beliefs of key thinkers in the field (Nutbrown \& Clough, 2014). In this section, I explore Isaacs' values and consider how these may have influenced my own education and career in England since the 1960s.

\section{Isaacs' values}

Isaacs' work was underpinned by her 'beliefs about the nature of knowledge, knowing and learning' in the field of ECE (i.a. Isaacs, 1930, 1933, 1944a): the 'personal epistemology' she had developed based on her influences, education and experience (Hofer \& Pintrich, 1997; Perry, 1970).

Isaacs (1954, pp. 20-21) was concerned about young children's affective needs and regarded 'warm human relationships' and children's security as paramount for effective ECE. She also encouraged MHS staff to give children time, space and freedom to resolve their own conflicts with one another (Nutbrown \& Clough, 2014, p. 53). Indeed, her belief that young children need 'opportunity for self-assertion and independence' extended to all aspects of their nursery experience (Isaacs, 1954, p. 22). Isaacs (1954, p. 31) had a high regard for young children's home environments: she considered nursery 'an extension of the function of the home, not a substitute'.

Isaacs also valued focus on the individual child at MHS. As an advocate for 'child-centred education', she emphasized children's 'individual development' and their own interests and she 'wanted to stimulate the active inquiry of the children' (Isaacs, 1930, p. 17; Nutbrown \& Clough, 2014, p. 53; Willan, 2011, p. 208).

Isaacs believed that 'scientific study gives (educators) knowledge of children's needs' and that the early childhood educator's role should include 'scientific understanding as well as mother wit and mother love' (Isaacs, 1954, p. 6, 30), 'knowledge of the psychological needs of children ... requirements for bodily health, and understanding of modern methods of education' (Isaacs, 1945, p. 236). She advocated for questioning, curious children and early childhood educators (David, 2005) and she valued 'understanding children's minds and emotions' (Shapira, 2017, p. 525), regarding 'deep observation (as) the key to understanding the complex and unique realities of individual children' (Willan, 2009, p. 151).

Isaacs $(1954$, p. 20, 29) advocated for plenty of space and 'real and active experience' as key features for how young children learn best. Regarding what young children should learn, she rejected a formal curriculum, instead offering a wide range of experiences indoors and outside to generate young children's interest in learning (Nutbrown \& Clough, 2014, p. 53; Willan, 2009, p. 156). MHS aims were:

(a) to provide for the development of the child's own bodily and social skills and means of expression; and (b) to open the facts of the external world (the real external world, that is, not the school "subjects") to him [sic] in such a way that he can seize and understand them. (Isaacs, 1930, p. 20) 
Isaacs believed in 'the great educational value of play' (Isaacs, 1929, p. 10), writing that 'Play is indeed the child's work, and the means whereby he grows and develops' (Isaacs, 1929, p. 9). She posited that free flow play enables young children's engagement in higher order thinking, diverging from Piaget's view whose stage theory findings emerged from the laboratory (Willan, 2009, p. 155).

At MHS, Isaacs regarded every child as a researcher who constructs knowledge through discovery and inquiry (Isaacs, 1944a, p. 352; Rickman, 1950, p. 280), arguing that 'The child's cognitive act is similar ... to his later acts of understanding, of reasoning, or of practical organization, as a historian, a scientist or a man of affairs' (Isaacs, 1930, p. 65).

\section{Disciplines and values}

Over sixty years after Isaacs completed her initial training to teach infants, I completed my own through the Bachelor of Education (B.Ed.) degree route. Typically for the early 1980s in England, my first degree included modules in pedagogy and curriculum, alongside four 'foundation disciplines': philosophy, sociology, education history, and psychology incorporating child development (Biesta, 2020; Bridges, 2006, p. 259; Robbins, 1963). Although Bridges (2006, p. 259) argues that the four-discipline initial teacher education (ITE) model was not wholly satisfactory, teacher competencies that replaced it later in the 1980 s were described as ' ... more suitable for plumbers than for teachers whose classroom behaviour had to be sensitive and flexible' (Lawton, 2005, p. 112).

Indeed, applications of multiple disciplines can be helpful for resolving complex 'real world' problems in dynamic contexts (Palaiologou, 2010, p. 275), and despite Bridges' (2006) misgivings, I emerged from my ITE with a grounding in each which helped me to develop values that have infused my work as an educator of young children and pre-service teachers in the field of early childhood education. They include: (i) foregrounding good relationships for young children's development and learning, (ii) equal importance afforded to young children's physical, emotional, social and intellectual development, (iii) young children's learning starts with their interests, (iv) educators' deep-level subject knowledge informs children's holistic learning, (v) inquiry, experience, activity, discovery and equal discourse as young children's primary modes of learning, (vi) the necessity of play for young children's development and learning, and (vii) cherishing and supporting young children as agentic learners. My values have remained constant despite the emergence of swathes of techno-rational education policy since my ITE in the early 1980s (Biesta, 2020).

These values are my 'personal epistemology' for the field of early childhood education, founded on my influences and experience (Hofer \& Pintrich, 1997; Perry, 1970). They are remarkably similar to Isaacs', outlined above. Indeed, many UK based early childhood educators have espoused beliefs congruent with Isaacs' (i.a. Fisher, 1996; Gammage, 2007; Nutbrown, 2012), though Isaacs' work tends to be cited less than some pioneers in the field. Contemporary statutory ECE policy in England has also reflected prima facie her values, with focus on 'the unique child', 'enabling environments', playing and exploring', 'creativity and critical thinking' and 'active learning' (DfE, 2017; 2020, p. 6,17$)$. These examples evidence the extent of Isaacs' influence on ECE, channelled through key policy documents including the Plowden report, her work as Head of the Department of Child Development at the Institute of Education, University of London and her writing based on research (CACE, 1967; Gardner, 1969; Isaacs, 1930, 1933).

\section{Isaacs' engagement with pedagogy, philosophy and psychology}

Though rather different from my own, Isaacs also experienced a formal education that included consilience of PPP. She learned about pedagogy during her initial training for infant teaching at the University of Manchester, moving on to study for a Bachelor's degree in philosophy for which she gained a first classification, progressing to research at University of Cambridge where she was awarded a Master's degree in psychology (Willan, 2011). At Cambridge she became interested in biological aspects of psychology: Isaacs connected ecology and psychology, recognizing the influence of 
the environment on children's intellectual development (Cameron, 2006, p. 860; Gardner, 1969, p. 166; Isaacs, 1921), and she recommended that educators should draw on their knowledge of 'psychology and pedagogy' to inform experiential provision for young children, for example, keeping mice as pets to learn aspects of biology (Isaacs, 1930, pp. 168-170).

Before she worked at MHS, Isaacs had learned much about the ideas of psychologists and progressive education philosophers, theorists and educators, including Pestalozzi, Froebel, Rousseau, Montessori, Gesell, Piaget and Dewey, which she critiqued and adopted judiciously for her own work (Graham, 2009; Isaacs, 1930). In 1924, Isaacs carried this learning about PPP into her role as co-founder, head teacher, early childhood educator and researcher at MHS. There, her work was oriented to learning about young children's development (Gardner, 1969; Isaacs, 1954) and her research findings concerning young children's 'discovery, reasoning and thought' at MHS that featured in her book 'Intellectual Growth in Young Children' are especially salient for the present article (Isaacs, 1930, p. 111).

Isaacs conducted her research at MHS between 1924 and 1927. It was a progressive school in Cambridge, England for children aged 2-10 years (Bar-Haim, 2017; Graham, 2009). Her research and progressive practice were founded on the extensive knowledge she had acquired through her formal education spanning initial teacher training, philosophy, psychology, and the experiential learning afforded to her as a psychoanalyst, ECE educator and researcher (Graham, 2009). Working with children of the Cambridge intelligentsia at MHS, Isaacs (1930, pp. 22-23) had two research aims: '(1) To find suitable ways of giving satisfaction to (finding out) among all the other educational impulses of children and (2) To discover the beginnings of the scientific spirit and scientific method in the thought of young children'. Isaacs' research at MHS built evidence for the claim that 'epistemic interest ... is in every respect the same in the child as in the adult' and that young children behave 'like the best sort of scientist' (Graham, 2009; Isaacs, 1944b, p. 322). In her practice at MHS, she drew on PPP to recognize ways young children's thinking is manifested in their actions, and she used that information to leverage young children's learning, reporting her findings so other early childhood educators may learn from them (Isaacs, 1930).

\section{Isaacs at MHS}

In her research with children at MHS, Isaacs adopted scientific method to address the philosophical questions 'How can we find out?' and 'How do we know?' by (Craig, 2002, p. 1). She and her coworkers identified 'conditions of observation' and created qualitative records of young children's 'discovery, reasoning and thought' during daily activities at MHS, then she used her combined knowledge of PPP to conduct 'theoretical analysis' of the children's 'discovery, reasoning and thought' (Isaacs, 1930). MHS pedagogy centred on children's 'direct and concrete interests' and 'encouraging the children's own active efforts in as many directions as possible' through experiential learning (Isaacs, 1930, pp. 22-23; 80). Child obsenvations in that pedagogical context revealed that not only adults, but also children at MHS posed the philosophical questions 'How can we find out?' and 'How do we know?', through "whys" and "because's" and other logical questions and reasoning' (Isaacs, 1930, p. 52). These findings led Isaacs to evidence-based conclusions, including her recognition of young children's high order epistemic cognition (Greene et al., 2008) - and her rejection of maturation theory since young children 'reason quite successfully when their interests are engaged' in concrete experiences (Isaacs, 1930, p. 83). Isaacs (1930, p. 84) argued that young children's reasoning is characterized by 'noetic synthesis': the mental process of combining complex cognitive elements to elicit 'percepts, ideas, and concepts' (Stout, 1896, p. 1; Vanderkerckhove \& Panksepp, 2011, pp. 2017).

\section{Isaacs after MHS}

Isaacs reported her scientific findings at MHS in two books: 'Intellectual Growth in Young Children' and 'Social Development in Young Children' (Isaacs, 1930; 1933). Later, she drew on these texts as 
Head of the Department of Child Development at the Institute of Education, University of London to inform ITE (Gardner, 1969). To some extent, in 'Intellectual Growth of Young Children', Isaacs (1930) treats her deep knowledge of pedagogy and philosophy as tacit (Polanyi, 1966), in favour of foregrounding psychology. She states explicitly that the book 'is in large part psychological' (p.1), and indeed, around two thirds of the authors she cites to support her theorization in the book are psychologists, with the remaining third from pedagogy or philosophy (Isaacs, 1930). Yet Isaacs (1930, p. 22) also notes that she and her co-workers at MHS synthesized pedagogy and psychology and were 'carried into the remoter provinces of the philosophy of education by looking at these direct and concrete interests of intelligent young children'. Equally, her partner Nathan Isaacs with whom she worked at MHS had plans to take her work forward by developing MHS into an institute teaching 'Psychology, education and science' (Isaacs, 1926).

After she left MHS, Isaacs contributed to the Hadow report (1933) and the 1944 Education Act in the UK (HMSO, 1944), and she influenced the Plowden report (CACE, 1967; Hood, 2019): important policy in England that informed ECE and primary education practice powerfully in the mid- to late twentieth century. Consequently, as I grew up in England, my own education was strongly influenced by Isaacs' work: first as a child in primary school in the 1960 s, then during my 'First School' ITE during the early 1980 s. Later, I carried Isaacs' influence into my work as an ECE and primary school teacher for two decades, then as a teacher educator and researcher working in a University in the early twenty-first century, where I initiated YCAR 'to conceptualize ways that young children aged 4-8 years are researchers, can develop as researchers and may be recognized as researchers', and arrived at similar conclusions to Isaacs in regard to young children's epistemic cognition (Murray, 2017, p. 14).

\section{Research and epistemic cognition}

Epistemic cognition is 'what we think we know (and) how we think we know it' (Greene et al., 2008, p. 158). Isaacs' (1930) MHS research drew on PPP to enhance understanding about young children's epistemic cognition in everyday contexts. Since her MHS study, other research, including the YCAR study, has also drawn on PPP to further understanding about young children's epistemic cognition. The work of Gopnik and colleagues has been prominent, though includes little reference to pedagogy (Gopnik, 2009; Gopnik, Meltzoff, \& Kuhl, 1999). Forman (2010) draws on his narrative observations of young children to propose that two-year-olds engage in 'scientific thinking' when they predict and test their predictions through play to establish cause and effect. Hedges (2014) conducted participant observations of young children aged 1-5 years in 'play and learning settings' and illuminated young children's 'working theories ... to connect, edit and extend understandings' (p.36), and Chesworth (2019) has explored young children's interests in social play as leverage for knowledge acquisition. Hutt, Tyler, Hutt, and Christopherson (1989, pp. 222-227) observed young children in ECE settings, identifying categories of epistemic behaviour in their play that facilitated learning, including problem solving, exploration and 'productive behaviour' characterized by product development or skills acquisition. The Froebel Blockplay Research Group (1992) found that young children aged 3-6 years 'observed .... and conducted open ended experiments to check their ideas' (p.108) and would 'initiat(e) their own research into matters that interest and puzzle them', applying their learning 'to solve problems they have encountered... or have deliberately set themselves' (p.129). Hargreaves, Robson, Greenfield, and Fumoto (2014) observed and talked with children aged 3-5 years to establish that young children engage in creative thinking through exploration, persistence, involvement and enjoyment in everyday activities.

Hutt et al. (1989) and Hargreaves et al. (2014) developed their findings revealing aspects of young children's epistemic cognition into typologies of play and creative thinking, respectively. A wider range of categories of young children's epistemic cognition features in the MHS and YCAR studies (Isaacs, 1930; Murray, 2017): these are are presented, explained, exemplified and discussed below. 


\section{The Malting House School research design}

Isaacs' study (1930) was based on qualitative narrative observations of children's everyday activity in the progressive MHS over the period 1924-27. Isaacs (1930, p. 14) reports that up to twenty children aged 2.7-10.5 years were observed over the study's duration; they had above average intelligence and came from professional - even eminent - families. Observations were recorded daily in notebooks by educators, including herself: they 'noted things as fully as (they) could at the actual moment, and then dictated a fuller record from these notes on the same day' (Isaacs, 1930, pp. $1-2)$. Isaacs (1930, p. 2) then applied her 'own deductions and theoretical views' to the data, being careful to keep observation reports objective and separate from interpretations. (Table 1).

\section{The Young Children Are Researchers research design}

For the participatory YCAR study (Murray, 2017, p. 16), a 'jigsaw' methodology was developed, featuring constructivist grounded theory as the major approach, supported by critical ethnography, mosaic approach and case study, each serving its own purpose. Multiple data collection methods were used, including narrative and snapshot child observations. Ethical considerations infused both form and function of YCAR which was conducted according to British Educational Research Association (BERA) (2011) guidelines and institutional code and procedures. Data were co-constructed with participants in three phases:

(a) Professional education and ECE researchers $(n=30)$.

(b) Educators $(n=17)$ and mixed ability children aged 4-8 years $(n=138)$ in state maintained primary schools $(n=3)$ in England

(c) Children aged 4-8 years $(n=5)$ from (b) and their families at home.

Following inductive thematic analysis, a research behaviour framework (RBF) emerged from Phase 1 interview data. The 39 RBF behaviours were then applied to child observation data gathered with children, their teachers and parents, co-producing evidence that research behaviours - and therefore epistemic cognition - presented in children's quotidian activities at school (Phase 2) and at home (Phase 3). Participant professional researchers participated in a nominal group exercise (Delbecq \& Van de Ven, 1971) to rank the behaviours in order of importance for research. The four most important were: exploration, finding solutions, conceptualization and basing decisions on evidence. These were then thematically analysed in greater depth and detail to elicit epistemic categories (Table 2) that act as affordances for the research behaviours young children use to construct knowledge. Epistemic factors are cognate groupings of the epistemic categories

Table 1. Young Children's 'Discovery, Reasoning and Thought' (adapted from Isaacs, 1930, p. 111).

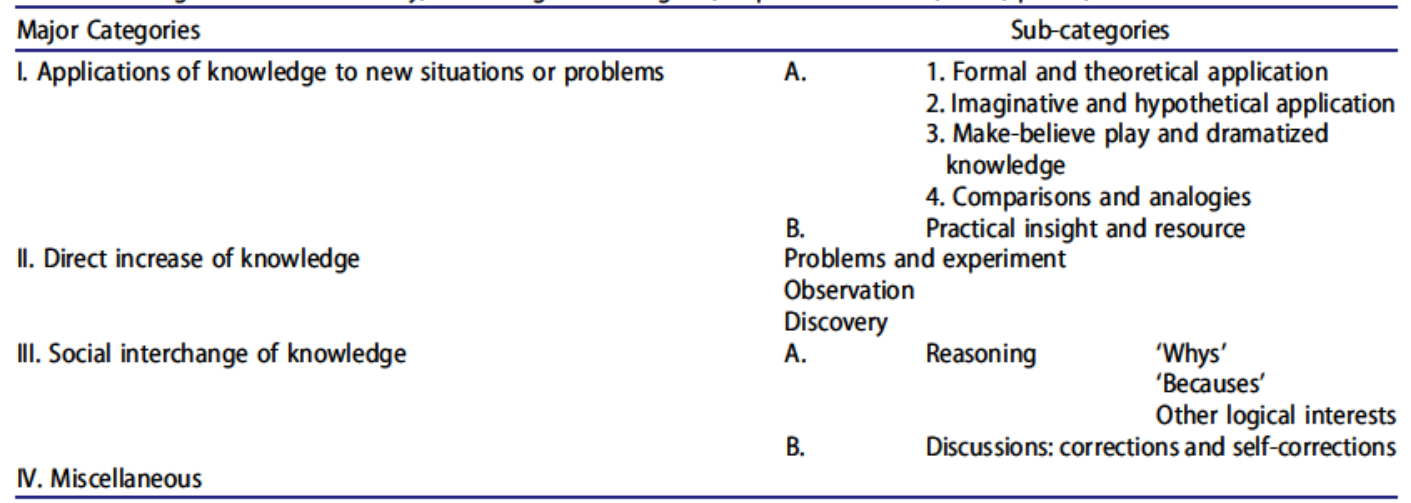




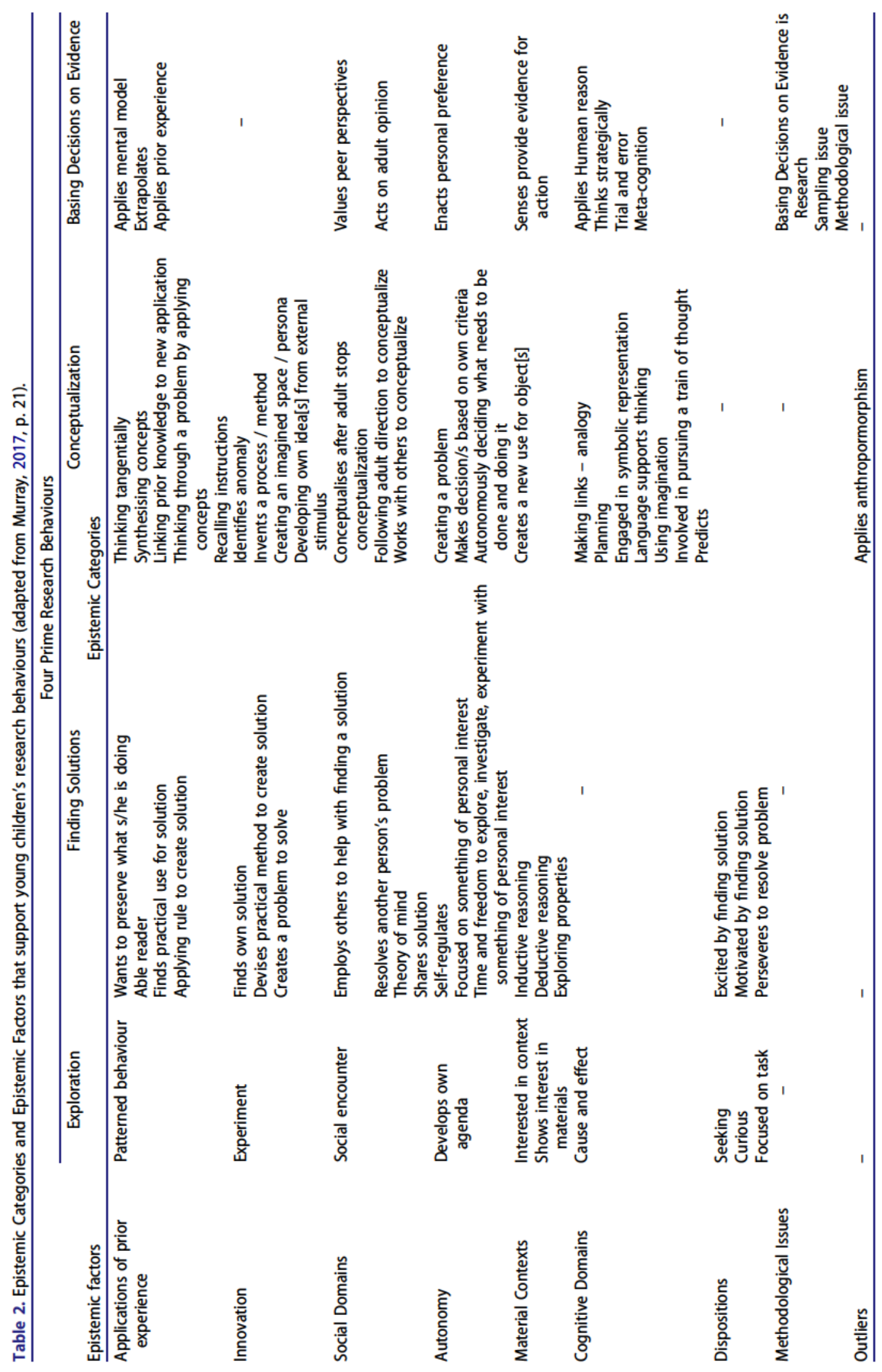


(Table 2). Research behaviours, epistemic factors and epistemic categories are features of epistemic cognition - 'what we think we know (and) how we think we know it' (Greene et al., 2008, p. 158).

\section{Consilience and young children's epistemic cognition}

This section considers how the consilience of PPP informed theorization in the MHS and YCAR studies (Isaacs, 1930; Murray, 2017) to assert that young children engage in high level epistemic cognition - 'what we think we know (and) how we think we know it' (Greene et al., 2008, p. 158). Both studies were conducted with young children, but each had different aims and the YCAR study was guided predominantly by a constructivist grounded theory approach so that its design and data grew inductively from its participants' input (Charmaz, 2006; Murray, 2017). The YCAR study was not designed to align with Isaacs' MHS study. Many key authors from PPP are cited to support YCAR findings (Murray, 2017); conversely, Isaacs' connections between her own MHS findings and extant PPP literature are often indirect or even tacit, though her theorization includes reference to more than 30 key PPP authors. Whilst there are significant differences between the MHS and YCAR studies, and they were conducted more than eight decades apart, some striking similarities are apparent in their findings. Several themes are cognate to both studies (Tables 1 and 2). The section below, structured according to Isaacs' 'major categories' of 'Young Children's Discovery, Reasoning and Thought (1930, p. 111) ('miscellaneous' apart), critiques selected findings from both studies.

\section{Applications of knowledge to new situations or problems}

Isaacs (1930) and Murray (2017) found that young children can and do apply what they know to new situations. Isaacs (1930) identified four types of 'applications of knowledge to new situations or problems' in the activity of children aged predominantly 3-7 years (Table 1) whilst within the YCAR epistemic factor 'applications of prior experience', twelve categories emerged across the four prime research behaviours presented by children aged 4-8 years (Table 2). Isaacs (1930, p. 111) highlights Dan's exposition of perspective as an example of 'formal and theoretical application' of knowledge to a new situation (Figure 1):

The YCAR study highlighted 'synthesize concepts' as an epistemic category of children's applications of prior experiences (Figure 2):

Dan combined his sensory experience of seeing the picture of aeroplanes with knowledge he had gained previously about the terms 'big' and 'small' to conclude - and communicate - that the positioning of the aeroplanes affects the appearance of their size. Gemma synthesized her earlier firsthand sensory experience of making cookies with her procedural knowledge (Ryle, 1949) of cookie-making processes and applied these with other materials to create a new pretend cookie.

In theorization of these data, PPP all play a part. Both examples demonstrate interactionist pedagogic approaches (Sylva et al., 2010): Dan had previously been taught the meaning of the terms 'big' and 'small', and Gemma had been taught the cookie making process; both then had opportunities to apply their learning in new contexts they had chosen autonomously. Dan and Gemma also demonstrate a posteriori (synthetic) reasoning: the philosophical process of making a judgement by

'When looking at a picture of aeroplanes, showing some on the ground and some in the air, Dan said (3.8) "When they are on the ground they are big and when they are up in the sky they are small"'

(Isaacs, 1930:111)

Figure 1. Dan applies knowledge. 
'Gemma (aged 5) had just finished making cookies with 'Smarties' (hard round candy sweets) on top of each with her Grandma and brother at home. The cookies were baking. Gemma put a bowl upside-down on the kitchen counter. Next, she said: "And then...the topping." Gemma saw a coin on the counter and picked it up. "This coin!" Gemma put the penny on top of the pot.'

Figure 2. Gemma applies knowledge.

Frank (5.8) saw a stick floating on the water in a bowl and put other things in to see if they would float - a penny, scissors, a piece of plasticine, a shell, a piece of chalk, paper, a pencil, a tin lid, etc. He said: 'All the things made of wood will float.' (Isaacs, 1930:126-7).

Figure 3. Frank experiments.

combining first-hand sensory experience with mental activity (Kant, 1787). In doing so, both children used their cognitive abilities to create a causal sequence by connecting separate events, a process recognized by psychologists (Teymoori \& Trappes, 2017).

\section{Direct increase of knowledge: experimenting}

Young children demonstrated their ability to experiment in both studies (Isaacs, 1930; Murray, 2017). In the YCAR study, experimenting is characterized by planning, controlling variables, assigning random individuals or objects to a group and manipulating treatment conditions (Creswell, 2008; Robson, 1993). It is connected with the epistemic factor 'innovation': something of value developed from a new idea (DBIS, 2011; 2012), and is also a category of the research behaviour 'exploration', which involves examining, analysing or investigating, examining for diagnostic reasons, or testing or experimenting to gain understanding (Stebbins, 2001, p. 2).

Isaacs (1930, p. 111) theorized that young children experiment to increase their knowledge, which she regarded a principle category of 'discovery, thought and reasoning'. She observed Frank setting up an experiment to see if objects made of different materials float (Figure 3):

In YCAR, Pedro also experimented (Figure 4):

Frank planned and controlled variables by selecting objects made of different materials, he assigned objects to a group, and he manipulated treatment conditions by placing selected objects in the water (Creswell, 2008, p. 300). He explored as researchers explore: investigating, examining the objects in water to diagnose the results, and he experimented to gain understanding

Pedro (aged 4) chose to go to the Safari role play area (outdoors)... where a large mound of earth had been left by builders the previous week... First, Pedro collected a pair of binoculars, then he used them to look at pictures of animals placed earlier by a practitioner on the fence surrounding the outdoor area. Pedro then lowered the binoculars to survey a rock within the mound of earth on the ground. He lifted the rock and studied it closely through the binoculars

(Murray, 2017: 35; Murray, 2021 in press) 
(Stebbins, 2001, p. 2). Following his experiment, Frank reported that 'All the things made of wood will float' indicating that he had gained knowledge (Isaacs, 1930, p. 127). Frank was innovative: his report suggested that he valued his finding (DBIS, 2011, 2012).

Pedro also experimented. Ahead of his investigation he collected binoculars, indicating that he planned (Robson, 1993, p. 78). Next, he assigned random objects to be observed, he controlled variables by consistently using his binoculars to observe, and he manipulated treatment conditions by working incrementally, observing the rock on the ground before lifting it towards his binoculars (Creswell, 2008, p. 300). Pedro had the idea to develop his own procedure for using binoculars to test the physical properties of a rock: something of value (DBIS, 2011, 2012). Like Frank, Pedro behaved as a researcher by exploring (Stebbins, 2001): he tested his binoculars by looking at the animal pictures his educator had provided, then used binoculars to examine the physical properties of the rock.

Again, the influence of PPP infuses the theorization of these observation data (Isaacs, 1930; Murray, 2017). Both children experienced child-led pedagogy that afforded them opportunities to construct their own learning actively, freely and independently 'through play and discovery' (Rugg \& Shumaker, 1928; Ryan, 2005, p. 99). In each case, adults had afforded them access to resources, 'time and freedom to explore, investigate, experiment with something of personal interest' (another YCAR epistemic category), and adults observed, reported and interpreted Frank's and Pedro's activities to advance understanding about young children's constructions of knowledge. Both vignettes exemplify Hume's important 'principle of verification' (Hume, 1748-2000, p. 123) for which 'learned work' features 'experimental reasoning concerning matter of fact and existence'. This link to philosophy was made explicitly in respect of Pedro's activity in the YCAR study (Murray, 2017); in the MHS study (1930, pp. 125-127), Isaacs recognized the philosophical connection by categorizing Frank's activity as 'Increase of knowledge; problems of experiment, observation and discovery'. Both Frank and Pedro adopted procedures commonly used by psychology researchers 'observation, experimentation and analysis' - (APA, 2020); equally, MHS and YCAR study data were derived using these same methods (Isaacs, 1930; Murray, 2017).

\section{Social interchange of knowledge: reasoning}

Young children provided evidence of their ability to reason in the MHS and YCAR studies (Isaacs, 1930; Murray, 2017), with many examples of a priori reasoning - mental activity only - and a posteriori reasoning - combining sensory experience with mental activity (Kant, 1787) - in both studies. Some of these examples were captured in social contexts. In the MHS study, Isaacs (1930, p. 149) reported the following dyad between Lena and Miss $C$., one of the Malting House educators (Figure 5):

The YCAR study included the observation below, conducted by a family at home (Murray, 2013) (Figure 6):

Although these observations were made 83 years apart, the dyads in Figures 5 and 6 are two examples among many in the MHS and YCAR studies providing rich evidence that young children reason logically by 'working with others to conceptualise', denoted as an epistemic category in the

'Lena (4.2) said to Miss C. (who is tall), "Why are you tall" and Miss C. said: "I don't know, I grew tall". She put her hand a little above Miss C.'s knee and said, "You were once as little as that when you were little"; and then putting her hand below the knee asked, "Were you as little as that when you were little - a little baby? Stand up as high as you can. You are tall!"'

(Isaacs, 1930:149) 


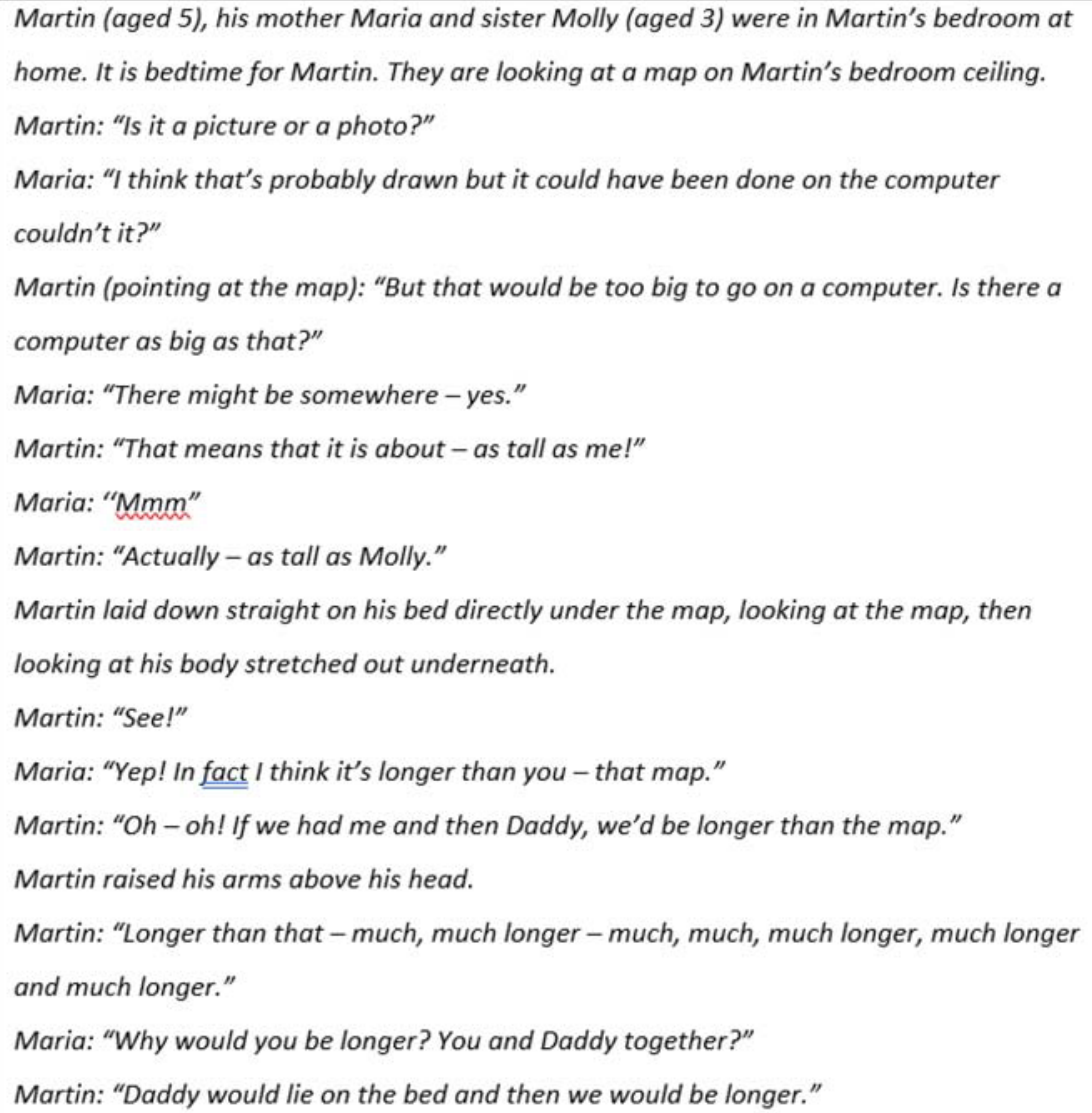

Figure 6. Martin reasons.

YCAR study (Murray, 2017). Concepts are defined as active ways to think, featuring 'clearly specified ideas deriving from a particular model' (Mensch, 2011; Silverman, 2006, p. 400) and conceptualization the ' ... process of thinking about a problem situation through particular "concepts"' (Metcalfe, 2007, p. 149). In different ways, both studies emphasize the value of social interaction as an affordance for young children's knowledge construction. Isaacs (1930, p. 111) posits that the role of social interaction in learning is evidenced in children's reasoning through 'why' questions, 'because' answers, 'other logical interests', and through 'discussions, with corrections and self-corrections'; in the YCAR study, Murray (2017) identifies 'social domains' as an epistemic factor that acts as an affordance for young children's research behaviour.

In the MHS dyad between Lena and Miss C, child-led pedagogy is evident: although Lena endeavours to draw Miss $C$. into equal dialogue, Miss C.'s response is minimal, leaving Lena to construct understanding herself (Ryan, 2005). Conversely, the YCAR dyad exemplifies an interactionist listening pedagogy in which knowledge is co-constructed through social engagement (Edwards et al., 1993). Both dyads feature examples of young children engaging in a posteriori reasoning by combining their sensory experiences of sight and touch with mental activity to develop logical arguments (Kant, 1787; Mensch, 2011; Metcalfe, 2007, p. 149; Silverman, 2006, p. 400). Although only the YCAR study refers explicitly to this key tenet of reasoning in the philosophical literature (Murray, 2017), Isaacs' knowledge of philosophy was embedded in her use of the term 'reasoning' as a major finding in the MHS study (1930). The new field of psychology emerged strongly in the early twentieth century (Wertheimer \& Puente, 2020) and this may be why explicit focus on literature 
from philosophy and pedagogy tends to be less prominent in Isaacs (1930) than her reference to contemporary psychology works (i.a. Gesell, 1928; Searl, 1924; Spearman, 1923) and her adoption of the psychologists' habitus in setting out her records and theoretical analysis.

\section{Implications and conclusions}

This article has explored the enduring significance of Susan Isaacs' work for ECE in the twenty-first century. It has considered Isaacs' values in ECE, discernible in current policy (DfE, 2017, 2020, p. 6, 17) with evidence to suggest that her belief in child-led pedagogy could be leveraged today for young children's learning. Equally, Isaacs' 1920s research highlighting young children's epistemic cognition has been examined in the context of recent studies in which findings resonate with Isaacs', suggesting benefits in continuing to build on her research. Furthermore, Isaacs' pioneering applications of the consilience of PPP to shape her values, guide practice, interpret young children's actions and develop the ECE field have influenced generations - myself included - through policy development, teacher education programmes, and key texts, suggesting that the currency of Isaacs' work prevails in ECE today (Hood, 2019; Willan, 2009).

\section{Lasting effects of Isaacs' values}

Isaacs' values in ECE are evident in the ECE statutory framework in England which features 'the unique child', 'enabling environments' playing and exploring', 'creativity and critical thinking' and 'active learning' (DfE, 2017, 2020, p. 6, 17). The link between child-led pedagogy and children's epistemic cognition is a potentially powerful vestige of Isaacs's work for twenty-first century ECE. She conducted her research in a child-led pedagogic context characterizing her values; an important conclusion to the MHS study was that 'epistemic interest and inquiry ... is in every respect the same in the child as in the adult' (Isaacs, 1944b, p. 322). Her findings suggest that child-led pedagogy may be beneficial for optimizing young children's learning. Recent research, including the YCAR study, accords with Isaacs' view that young children can - and do - engage in high level epistemic cognition in contexts that provide appropriate affordances (Gopnik, 2009; Hargreaves et al., 2014; Hedges, 2014; Murray, 2017). Indeed, epistemic factors and epistemic categories in the YCAR study findings support the value of child-led learning, for example 'autonomy' and 'time and freedom to explore, investigate, experiment with something of personal interest' (Murray, 2017).

\section{Building on Isaacs' research: what happens next?}

Isaacs' 1920s research, based on data that she and other MHS educators collected, and interpreted by Isaacs' theorization informed by her knowledge of PPP and the children, revealed many sophisticated, complex examples of young children's epistemic cognition that occurred in a child-led pedagogic context. Her research findings resonate with examples from contemporary studies identified in this article highlighting young children's adoption of epistemic cognition for constructing knowledge. For example, although MHS and YCAR studies were conducted more than eighty years apart, had different aims, different research designs and engaged with different demographic groups of participant children (Isaacs, 1930; Murray, 2017), both studies found that young children engage in epistemic cognition and do so naturally to learn during their everyday activities (Greene et al., 2008; Isaacs, 1930; Murray, 2017). The reflection of Isaacs' ideas in these studies evidences her strong legacy to the ECE field, and their researchers' recognition that there is value in continuing to build in the twenty-first century on her ideas: Isaacs' research has relevance for contemporary ECE researchers and practitioners. In terms of what happens next, YCAR continues (Murray, 2020): young children's engagements have been investigated in depth in respect of only ten of the 39 research behaviours identified early in the study and 29 have yet to be interrogated more fully. This work will continue to add to our understanding of young children's epistemic cognition, 
alongside other current studies promising further exciting possibilities. Examples include Gopnik (2020) and her team who are exploring '... how children ... figure out psychological causality'. Equally, Chesworth is currently investigating how young children's working theories, funds of knowledge and interests present in play to inform learning (University of Sheffield, 2020), and the 'Learning Spaces' project recognizes young children's critical thinking and investigative skills (Boulder Journey School, 2020). Each of these studies draws on at least two of the PPP disciplines.

\section{The enduring consilience of pedagogy, philosophy and psychology: what happens next?}

Isaacs pioneered applications of the consilience of PPP to shape her values, guide practice, interpret young children's actions and develop the ECE field through policy development, teacher education programmes, research and publications. The three disciplines on which Isaacs drew for theorizing her findings remain intrinsic to practice and research in the ECE field today. Research is not a neutral space: researchers enter it encumbered by influences and their own values (Scott, Richards, \& Martin, 1990). Whilst pedagogic and philosophical ideas had already been informing ECE for many years before MHS opened, psychology was a new discipline when Isaacs conducted the MHS study. She pioneered use of its literature alongside pedagogic and philosophical literature to theorize observation data for ECE research: Isaacs was influenced by authors in all three disciplines. Since Isaacs' MHS study, PPP literature has permeated the ECE field, and Issacs' influence on education and ECE in England has been substantial (Hood, 2019; Willan, 2009). I was educated in England and have worked in ECE for many years in different roles: the same three disciplines that informed Isaacs' MHS work have informed mine, among many others, in part due to Isaacs' influence (1930).

Going forward, Isaacs' practice as an educator and researcher provides a worthy model for ECE today and into the future, with the potential to benefit not only privileged children, but all children. However, this proposition is contingent on early childhood educators whose practice is guided by values for which they have a strong rationale, who have ability and capacity to engage in enquiry in their settings, and who are knowledgeable about pedagogy, philosophy and psychology relevant to ECE and skilled in applying that knowledge. Such practice requires that all early childhood teachers are highly educated and strongly motivated. In consideration of what might happen next, then, policymakers are encouraged to make adequate provision for the education, recruitment and retention of such a workforce for all young children.

\section{Disclosure statement}

No potential conflict of interest was reported by the author(s).

\section{Notes on contributor}

Jane Murray PhD is Associate Professor and Co-Director at the Centre for Education and Research, University of Northampton, UK. Her research interests include early childhood education and social inclusion and she has published extensively in these areas.

\section{ORCID}

Jane Murray (D) http://orcid.org/0000-0001-7000-0901

\section{References}

American Psychological Association (APA). (2020). About APA. Retrieved from https://www.apa.org/about Audi, R. (1998). Epistemology. London: Routledge.

Bar-Haim, S. (2017). The liberal playground: Susan Isaacs, psychoanalysis and progressive education in the interwar era. History of the Human Sciences, 30(1), 94-117. doi:10.1177/0952695116668123 
Biesta, G. (2020). Educational research. London: Bloomsbury.

Boulder Journey School. (2020). Publications: Learning spaces. Boulder Journey School. Retrieved November 4, 2020 from https://families.boulderjourneyschool.com/publications.html

Bridges, D. (2006). The disciplines and discipline of educational research. Journal of Philosophy of Education, 40(2), 259272.

British Educational Research Association (BREA). (2011). Ethical guidelines for educational research. London: Author.

British Psychological Society (BPS). (2020). What is psychology? Retrieved from https://www.bps.org.uk/public/what-ispsychology

CACE. (1967). Children and their primary schools (The Plowden report). London: Her Majesty's Stationery Office.

Cameron, L. (2006). Science, nature, and hatred: 'Finding out' at the Malting House Garden school, $1924-29$. Environment and Planning D: Society and Space, 24(6), 851-872.

Charmaz, K. (2006). Constructing grounded theory. London: Sage.

Chesworth, L. (2019). Theorising young children's interests: Making connections and in-the-moment happenings. Learning, Culture and Social Interaction, 23(3), 100263.

Chung, S., \& Walsh, D. J. (2000). Unpacking child-centredness: A history of meanings. Journal of Curriculum Studies, 32(2), 215-234. doi:10.1080/002202700182727

Craig, E. (2002). A very short introduction to philosophy. Oxford: Oxford University Press.

Creswell, J. (2008). Educational research. Upper Saddle River, NJ: Pearson.

David, T. (2005, January 10). Early years pioneers: Susan Isaacs. Nursery World. Retrieved September 17, 20 from https:// www.nurseryworld.co.uk/features/article/early-years-pioneers-susan-isaacs

DBIS. (2011). Innovation and research strategy for growth business, innovation and skills. London: DBIS.

DBIS. (2012). Innovation. Retrieved November 4, 2020, from http://www.bis.gov.uk/innovation

Delbecq, A. L, \& Van de Ven, A. H. (1971). A group process model for problem identification and program planning. The Journal of Applied Behavioral Science, 7, 466-492.

Dewey, J. (1897). My pedagogic creed. The School Journal, 54(33), 77-80.

Dewey, J. (1916). Democracy and education. London: MacMillan.

DfE. (2017). Statutory framework for the early years foundation stage. Retrieved November 4, 2020, from https:/assets. publishing.service.gov.uk/government/uploads/system/uploads/attachment_data/file/596629/EYFS_STATUTORY_ FRAMEWORK_2017.pdf

DfE. (2020). Statutory framework for the early years foundation stage. Retrieved November 4, 2020, from https://assets. publishing.service.gov.uk/government/uploads/system/uploads/attachment_data/file/896810/EYFS_Early_ Adopter_Framework.pdf

Edwards, C., Gandini, L., \& Forman, G. (1993). The hundred languages of children. Norwood, NJ: Ablex.

Fisher, J. (1996). Starting from the child. Milton Keynes: Open University Press.

Forman, G. (2010). When 2-year-olds and 3-year-olds think like scientists. Early Childhood Research and Practice, 12(2). Retrieved November 4, 2020, from https://ecrp.illinois.edu/v12n2/forman.html

Froebel, F. (1826). On the education of Man. Keilhau: Wienbrach.

Froebel Blockplay Research Group. (1992). Children being scientific and solving problems. In P. Gura (Ed.), Exploring learning: Young children and block play (pp. 107-131). London: Paul Chapman Publishing.

Gammage, P. (2007). None so blind: Early childhood education and care - The connective tissue. Forum, 49(1-2), 47-54. Gardner, D. (1969). Susan Isaacs: The first biography. London: Methuen Educational Ltd.

Gesell, A. (1928). Infancy and human growth. London: Macmillan.

Giannoni, D. S. (2010). Mapping academic values in the disciplines: A corpus-based approach. Bern: Peter Lang.

Gibney, E. (2012). Evolutionary philosophy: Life makes sense. Morrisville, NC: Lulu.com.

Gopnik, A. (2009). The philosophical baby. New York: Farrar, Straus and Giroux.

Gopnik, A. (2020). Alison Gopnik Research. Retrieved November 4, 2020, from http://alisongopnik.com/Alison_Gopnik_ Research.htm

Gopnik, A., Meltzoff, A. N., \& Kuhl, P. K. (1999). The scientist in the crib. New York: HarperCollins.

Graham, P. (2008). Susan Isaacs and the Malting House School. Journal of Child Psychotherapy, 34(1), 5-22. doi:10.1080/ 00754170801896035

Graham, P. (2009). Susan Isaacs: A life freeing the minds of children. Abingdon: Routledge.

Greene, J. A., Azevedo, R., \& Torney-Purta, J. (2008). Modeling epistemic and ontological cognition: Philosophical perspectives and methodological directions. Educational Psychologist, 43(3), 142-160. doi:10.1080/00461520802178458

Hadow, W. (1933). The Hadow report: Infant and nursery schools. London: HM Stationery Office.

Hargreaves, D. J., Robson, S., Greenfield, S., \& Fumoto, H. (2014). Ownership and autonomy in early learning: The Froebel Research Fellowship project, 2002-2015. Journal of Early Childhood Research, 12(8), 308-321. doi:10.1177/ $1476718 \times 14536718$

Hedges, H. (2014). Young children's 'working theories': Building and connecting understandings. Journal of Early Childhood Research, 12(1), 35-49. doi:10.1177/1476718X13515417

HMSO. (1944). Education Act 1944. London: HMSO. 
Hofer, B. K., \& Pintrich, P. R. (1997). The development of epistemological theories: Beliefs about knowledge and knowing and their relation to learning. Review of Educational Research, 67(1), 88-140. doi:10.3102/00346543067001088

Hood, P. (2019). Does early childhood education in England for the 2020s need to rediscover Susan Isaacs: Child of the late Victorian age and pioneering educational thinker? Genealogy, 3, 39.

Hume, D. (1748-2000). An enquiry concerning human understanding. In T. Beauchamp (Ed.), David Hume: An enquiry concerning human understanding (pp. 5-123). Oxford: Oxford University Press.

Hutt, C., Tyler, S., Hutt, C., \& Christopherson, H. (1989). Play, exploration and learning. London: Routledge.

Isaacs, N. (1926). Psychology, education and science. Institute of Education Archives, N1/B/6.

Isaacs, N. (1944a). Education and science. In S. Isaacs (Ed.), Intellectual growth in young children (pp. 350-354). London: Routledge.

Isaacs, N. (1944b). Children's 'why' questions. In S. Isaacs (Ed.), Intellectual growth in young children (pp. 291-349). London: Routledge.

Isaacs, S. (1921). An introduction to psychology. London: Methuen.

Isaacs, S. (1929). The nursery years. London: Routledge and Sons.

Isaacs, S. (1930). Intellectual growth in young children. London: Routledge and Sons.

Isaacs, S. (1933). Social development in young children. London: Routledge and Sons.

Isaacs, S. (1945). Children in institutions. In S. Isaacs (Ed.), Childhood and after: Some essays and clinical studies (pp. 208236). London: Routledge and Kegan Paul.

Isaacs, S. (1954). The educational value of the nursery school. London: The British Association for Early Childhood Education.

James, W. (1890). The principles of psychology. Vol. II. New York: Dover.

Kant, I. (1787). The critique of pure reason. Project Gutenberg. (Trans. J. Meiklejohn). Retrieved from http://www. gutenberg.org/ebooks/4280

Lather, P. (2006). Paradigm proliferation as a good thing to think with: Teaching research in education as a wild profusion. International Journal of Qualitative Studies in Education, 19(1), 35-57.

Lawton, D. (2005). Education and labour party ideologies 1900-2001 and beyond. Abingdon: RoutledgeFalmer.

Mensch, J. (2011). Intuition and nature in Kant and Goethe. European Journal of Philosophy, 19(3), 431-453.

Metcalfe, M. (2007). Problem conceptualisation using idea networks. Systemic Practice and Action Research, 20(2), 141150.

Montessori, M. (1912). The Montessori method. London: Willian Heinemann.

Murray, J. (2015). Early childhood pedagogies: Spaces for young children to flourish. Early Child Development and Care, 185(11-12), 1715-1732. doi:10.1080/03004430.2015.1029245

Murray, J. (2017). Building knowledge in early childhood education: Young children are researchers. Abingdon: Routledge.

Murray, J. (2018). Value/s in early childhood education. International Journal of Early Years Education, 26(3), $215-219$. doi:10.1080/09669760.2018.1490849

Murray, J. (2020). Young Children Are Researchers. University of Northampton. Retrieved November 4, 2020, from https:// mypad.northampton.ac.uk/ycar/

Murray, J. (2021). Young children's play, voices and rights in research. In L. Arnott \& K. Wall (Eds.) Research through play: Participatory methods in early childhood (in press). London: Sage.

Murray, J. (2013). An exploration of young children's engagements in research behaviour, PhD Thesis. University of Northampton, Northampton.

Nola, R., \& Irzik, G. (2006). Philosophy, science, education and culture. Dodrecht: Springer.

Nutbrown, C. (2012). Foundations for quality. London: Department for Education.

Nutbrown, C., \& Clough, P. (2014). Early childhood education: History, philosophy and experience. London: Sage.

Palaiologou, I. (2010). The death of a discipline or the birth of a transdiscipline: Subverting questions of disciplinarity within education studies undergraduate courses. Educational Studies, 36(3), 269-282. doi:10.1080/ 03055690903220180

Paris, J. (2017). Is psychoanalysis still relevant to psychiatry? The Canadian Journal of Psychiatry / La Revue Canadienne de Psychiatrie, 62(5), 308-312. doi:10.1177/0706743717692306

Perry, W. G. (1970). Forms of intellectual and ethical development in the college years. New York: Holt, Rinehart \& Winston. Polanyi, M. (1966). The tacit dimension. Chicago, IL: University of Chicago Press.

Powell, S. (2010). Hide and seek: Values in early childhood education and care. British Journal of Educational Studies, 58 (2), 213-229. doi:10.1080/00071001003752195

Rickman, J. (1950). Susan Sutherland Isaacs. International Journal of Psycho-Analysis, 31, 279-285.

Robbins, L. (1963). The report of the committee on higher education. London: Her Majesty's Stationery Office.

Robson, C. (1993). Real world research. Oxford: Blackwell.

Rugg, H., \& Shumaker, A. (1928). The child-centered school. New York: World Book Co.

Ryan, S. (2005). Freedom to Choose: Examining children's experiences in choice time. In N. Yelland (Ed.), Critical Issues in early childhood education (pp. 99-114). New York: Open University Press.

Ryle, G. (1949). The concept of mind. London: Penguin. 
Scott, P., Richards, E., \& Martin, B. (1990). Captives of controversy: The myth of the neutral social researcher in contemporary scientific controversies. Science, Technology, \& Human Values, 15(4), 474-494.

Searl, M. N. (1924). A child study. British Journal of Medical Psychology, 4(3), 249-257.

Shapira, M. (2017). 'Speaking Kleinian': Susan Isaacs as Ursula Wise and the Inter-War popularisation of psychoanalysis. Medical History, 61(4), 525-547. doi:10.1017/mdh.2017.57

Silverman, D. (2006). Interpreting qualitative data. London: Sage.

Spearman, C. (1923). ). The nature of 'intelligence' and the principles of cognition. London: Macmillan.

Stebbins, R. A. (2001). Exploratory research in the social sciences. Thousand Oaks, CA: Sage.

Stout, G. F. (1896). Analytic psychology. (Nol II). London: Routledge.

Sylva, K., Melhuish, E., Sammons, P., Siraj-Blatchford, l., \& Taggart, B. (2010). Early childhood matters. Abingdon: Routledge.

Teymoori, A., \& Trappes, R. (2017). A revolution in thinking. The Psychologist, 30, 92-95. Retrieved November 4, 2020 from https://thepsychologist.bps.org.uk/volume-30/july-2017/revolution-thinking\#

University of Sheffield. (2020). Dr Liz Chesworth: Research interests. University of Sheffield. Retrieved November 4, 2020 from https://www.sheffield.ac.uk/education/research/early-childhood/practitioners

Vanderkerckhove, M., \& Panksepp, J. (2011). A neurocognitive theory of higher mental emergence: From anoetic affective experiences to noetic knowledge and autonoetic awareness. Neuroscience and Biobehavioral Reviews, 35 (9), 2017-2025. doi:10.1016/j.neubiorev.2011.04.001

Warburton, N. (2013). Philosophy. 5th ed. Abingdon: Routledge

Wertheimer, M., \& Puente, A. E. (2020). A brief history of psychology. New York: Routledge.

Willan, J. (2009). Revisiting Susan Isaacs - A modern educator for the twenty-first century. International Journal of Early Years Education, 17(2), 151-165. doi:10.1080/09669760902982356

Willan, J. (2011). Susan Isaacs (1885-1948): her life, work and legacy. Gender and Education, 23(2), 201-210. doi:10.1080/ 09540253.2011.553822

Wilson, E. O. (1998). Consilience. London: Little, Brown and Co.

Wundt, W. (1896). Grundriss der Psychologie [Outline of psychology]. Leipzig: Engelmann. 